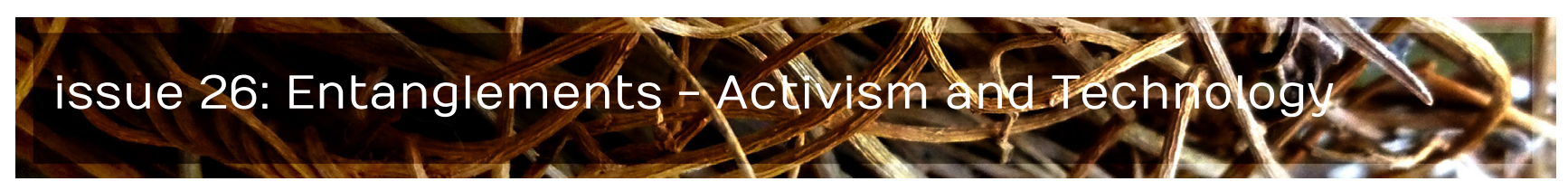

\title{
FCJ-193 Harbouring Dissent: Greek Independent and Social Media and the Antifascist Movement
}

\author{
Sky Croeser \\ Curtin University
}

Tim Highfield

Queensland University of Technology

\begin{abstract}
:
This article examines Greek activists' use of a range of communication technologies, including social media, blogs, citizen journalism sites, Web radio, and anonymous networks. Drawing on Anna Tsing's theoretical model, the article examines key frictions around digital technologies that emerged within a case study of the antifascist movement in Athens, focusing on the period around the 2013 shutdown of Athens Indymedia. Drawing on interviews with activists and analysis of online communications, including issue networks and social media activity, we find that the antifascist movement itself is created and recreated through a process of productive friction, as different groups and individuals with varying ideologies and experiences work together.
\end{abstract}

doi: $10.15307 /$ fcj.26.193.2015 


\section{Introduction}

Activists' uses of digital technologies are complex, and technologies are not only shaping the available possibilities for social change but are also being changed themselves through activists' work. In this article we look at Greek activists' use of a range of communication technologies, including social media like Twitter and Facebook, blogs, citizen journalism sites, Web radio, anonymous networks, and email. We use Anna Tsing's (2005) model of friction to understand how frictions might productively influence or slow the use of particular digital technologies, examining the intersections between human and non-human actors, ideologies and experiences, in influencing the choices made by activists.

Our analysis focuses on the Greek antifascist movement, primarily in Athens, noting that 'the antifascist movement' is largely a constructed object. We see Greek anarchist and anti-authoritarian organising as a key element of this movement, and note that E. Dimitris Kitis (2015: 2) has suggested that this be seen as a chóros (which translates to 'space', but is more accurately a 'scene' or 'milieu'), which 'replaces the notion of a specific social movement or subculture with one of a more fluid assortment of people and ideas, including one that is not even constant in nature and time'. However, we continue to use the term 'movement' here to emphasise (in line with Croeser, 2012; 2014) that no movements are as cohesive or as unitary as they are often depicted in social movement studies. Many of those we interviewed would also reject the label 'activist', and so while we use the words 'activist' and 'movement,' in doing so we attempt to problematise them. These terms are 'zones of awkward engagement, where words mean something different across a divide even as people agree to speak' (Tsing, 2005: xi). Anarchist and autonomous activists, immigrants trying to protect their communities, journalists, and others create unexpected and temporary alliances, even as differences continue to be important and, frequently, divisive. To the extent that there is such a thing as a Greek antifascist movement, it is not a pre-existing phenomenon which then uses social media in particular ways: rather, it is created and constantly recreated in new and slightly different ways through particular spaces and events, including through social media.

With these caveats in mind, we discuss this movement focusing specifically on its activities in April and May 2013, a period that saw the enforced shutdown of three independent media channels, including the Athens Indymedia site. This discussion must be put in the context of several interrelated trends affecting Greece. The economic crisis that was beginning to manifest in 2008 was accompanied by a shift towards austerity politics, leading to cuts to social support services and to the public sector, including media. At the same time, government control of public space and spaces of dissent was tightening, 
prompted in part by pressure from private interests and a strong relationship with private media. The economic crisis, bolstered by right-wing rhetoric from mainstream politics parties (particularly Nea Democratia or New Democracy) and Greek private television, exacerbated the xenophobia which had been rising in Greece since the 1990s (Psarras, 2013). These trends facilitated the growth of Chrysi Avgi, Golden Dawn, a neo-Nazi organisation officially founded in 1980 (Psarras, 2013: 6). The group, which had been largely irrelevant in previous decades, entered the Greek national parliament in 2012. Antifascist activists were therefore operating in a context where: Greek society had very high levels of racism; an openly fascist party had gained enough support to be represented in parliament; mainstream political parties were stoking the fires of xenophobia; attacks on independent media were increasing (as we discuss in more detail below); and there were signs of significant support for Golden Dawn among Greek police (Margaronis, 2012).

Pantelis Vatikiotis (2011: 172) has noted that prior to the 2008 protests (discussed below) little attention had been brought to bear on sub-cultures and social movements in the margins in Greece, and in particular there was limited work 'on grassroots media practices in Greece that have diachronically promoted the inclusion of marginalised social domains, heterogeneous discourses, and diverse social actors in public and political life.' Since 2008, work in this area has increased significantly, with extensive literature examining the 2008 protests (Karamichas, 2009; Sotiris 2010; Vradis and Dalakoglou, 2011; Kornetis, 2010; Chatzidakis, 2013; Kalyvas, 2010), and/or Greek activists' media practices (Milioni, 2009; Milioni and Panos, 2011). However, this literature has rarely examined the frictions in activists' use of different technologies - that is, the ongoing sparks and reorientations created by and through the relationships between activists' ideologies, the embedded affordances of technologies, and other actors.

The intersections between social movements and digital technologies, and the way these are changing over time, have been the subject of extensive international research across platforms and activist communities, from the Zapatista movement in Mexico in the 1990s to Occupy Wall Street and its offshoots (see, among others, Meikle, 2002; Papacharissi, 2015; Bennett and Segerberg, 2013). Tsing's model of frictions offers an opportunity to deepen this work by inviting us to consider 'the awkward, unequal, unstable, and creative qualities of interconnection across difference' (2005: 4). Although Tsing explores the model primarily in reference to the relationships between individuals and groups, friction can be extended as a useful metaphor for understanding our relationships with technology: activists' use of digital technologies involves similarly awkward, unstable, and creative connections across difference, both interpersonal and between human and non-human actors. 


\section{Leaving Exarcheia - the growth of the Athenian antifascist media ecology since 2008}

The Greek media environment has undergone significant changes since 2008 , and has been profoundly affected by austerity politics and the accompanying extension of mechanisms of social control. Early signs of the Greek impacts of the global capitalist crisis were seen in 2008, when negative growth rates in the economy were accompanied by increasing unemployment, and huge growth in poverty, social exclusion, and homelessness. The Greek government, in line with loan conditions imposed by the IMF, responded by slashing the social welfare net and cutting social services, including health services (Kondilis et al., 2013: e1). At the same time, the policing of public spaces and reports of police violence intensified (Occupied London Collective, 2011: 329; Sotiris, 2010). This combination of economic pressures and growing social controls set the scene for the events of December 2008.

Many commentators see the 2008 protests as creating a fundamental change in the Greek political landscape, and Giovanopolous and Dalakoglou have argued that, "any attempt to return to the pre-December 2008 political normalities is impossible at any level and for any actor in Greek political life' (2011: 112). The catalyst for 2008's massive protests was the murder of Alexandros Grigoropoulos, a 15-year old, by two policemen. Grigoropoulos was shot on 6 December in Exarcheia, a neighbourhood particularly associated with the anarchist movement or, as Makrygianni and Tsavdaroglou (2011: 40) describe it, "ground occupied by the antagonistic movement'. The response was swift, with mobilisation happening immediately through phone calls and the Indymedia site. One interviewee, Antonis Broumis, spoke of receiving a call from his brother, telling him about the murder, and about the failure of the mainstream media to provide useful information:

...because the mainstream media came out with a story, "we don't know who shot, maybe he still lives", when riots started everywhere the whole thing collapsed, because people knew through the Indymedia, not through the mainstream media.

The Indymedia Athens website was visited over ten million times in the days following Grigoropoulos' murder (Dalakoglou and Vradis, 2011: 18). As protests gathered force over the following days, communications over Indymedia and mobile phone networks continued to play a key role. 
Distrust of the mainstream media was exacerbated by the perceived misrepresentation of the Greek anti-austerity protests, centred on the occupation of Syntagma Square in Athens, in 2011 and 2012. Theocharis et al. argue that this was a central complaint amongst Greek protesters, and led to 'the Greek movement's explicit hostility towards mass media and to a turn towards alternative avenues for information' (2014: 210). Several interviewees noted that during the Syntagma Square protests, independent media played a key role. For example, an anonymous participant noted the importance of Radio Entasi's presence at the site of the occupation, 'between the teargas and the riot police', while another, IrateGreek, talked about the significance of the Syntagma protests in increasing use of the \#rbnews hashtag which has become central to RadioBubble's reporting (and indeed to much of the Greek news media ecology). As independent media sources expanded, they have contributed to the ongoing research and coverage of the relationship between the mainstream media and business elites (see for example, Inflammatory, 2013), many of whom have also been charged with fraud or linked to government corruption, reinforcing the distrust of mainstream media.

Both the Greek state and far-right groups have begun to respond to the growth of independent media and critical perspectives. Greek activists and commentators point to a number of moves by the Greek government that, they argue, aim to shut down dissent. IrateGreek argued that there is a pattern emerging in which the most marginalised spaces face repression first-as seen in the violent police closure of squatted social centre Villa Amalias described by Dalakoglou (2013)—with other spaces of dissent following. The shutdown and "reorganisation" of the national broadcasting station, ERT, in June of 2013 can also be seen in this light: journalists from the ERT, unions, and press freedom organisations framed this as an attack on democracy with chilling effects on media freedom (Lowen, 2013). It is frequently assumed that state attacks on spaces of dissent are closely tied to the interests of economic elites: for example, in an interview with Giorgos Kyritsis, a journalist from Avgi-a more mainstream left news publication which nevertheless sees its work as being aligned with the antifascist movement-he said, 'we have been sued many times, not from the government, from others, who happen to be friends with the government'. At the same time, Golden Dawn has been playing an active role in attacks on dissenting spaces, ranging from asking pointed questions about the location of Indymedia servers as early as 2009 (IMC, 2009) to engaging in what seem to be coordinated efforts to shut down Greek antifascist accounts on Facebook (Siapera, 2014; MatӨaíoc, 2013). Formal mechanisms of state repression combine in complex ways with other forms of control to put pressure on the growth of independent media.

The shutdown of Indymedia, Radio Entasi and 98FM needs to be understood in this context; while this is a relatively minor event in the history of the antifascist movement, it does highlight many of the broader trends affecting activists' use of digital technologies 
in Greece. The shutdown happened when servers hosting independent media sites were turned off on the order of the Dean of the National Technical University in Athens (NTUA) on 11 April 2013, but many commentators saw this as a result of pressure from the government, referencing a tweet from New Democracy MP Adonis Georgiadis

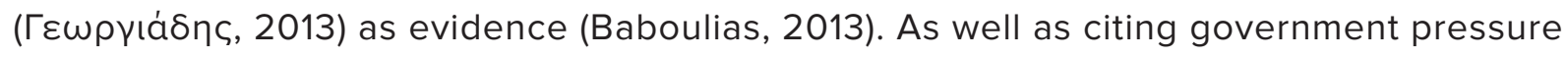
as a motivation, several interviewees noted ongoing questions from Golden Dawn in parliament and potential attempts by mining companies to undermine resistance to the Skouries mine in lerissos. As this shutdown demonstrates, activists clearly understand attacks on their communications and media as extending significantly beyond a model of state-based censorship, encompassing deeper concerns with the relationship between capitalism, state power, and communicative technologies.

\section{Research design and methodology}

This article forms part of our wider Mapping Movements project, which studies the intersections between social movements and technologies, taking in case studies from around the world: our research so far has also included fieldwork and online analysis of Occupy Oakland in the US (Croeser and Highfield, 2014) and the 2013 World Social Forum held in Tunisia. For the Greek case study, we use a mixed-methods approach combining fieldwork and interviews with activists in Athens with digital methods, drawing on hyperlink networks and Twitter data. This approach allows us to garner a more nuanced view of the movement and its relationship with online platforms than would be apparent from social media activity alone (see also approaches used by, for example, Gerbaudo, 2012). The methodology is designed as a means of overcoming some of the limitations found in social movement research, particularly around social media analysis. Our methods also respond to ethical concerns and challenges, which may be well documented by previous literature on social movements, but which have not yet received a consistent response in the case of social media studies.

We used IssueCrawler software to follow hyperlinks from a seed list of websites related to the movement (including blogs) to identify additional sites to which they are connected. The results of the crawls allow the identification of issue and solidarity networks, associated in some way with the movement (see, for example, Marres and Rogers, 2005; Bennett and Segerberg, 2013). The depth of the crawl also allows for examining whether a movement has connections to other issues and movements, at the local and international levels, or if it combines multiple issue networks (or indeed moves from a single-issue network to a wider, thematically-consistent network within which the single-issue networks are located). The value of identifying online issue networks is seen by how they highlight 
the resources, organisations, media, and other websites (including social media platforms) that are connected, cited, or invoked through hyperlinks from sites discussing a given issue. This is particularly important when considering how social movements might employ different platforms and sources over the course of a protest or campaign.

For our case study, we drew on seed lists of websites set up around the antifascist movement, and also sites covering and created in response to the specific event of the Athens Indymedia shutdown on 11 April 2013. Although Indymedia is not an antifascistspecific platform, the two contexts are linked, especially in the use of independent media by activists and the importance of these channels to movements covering a range of issues. Kriditis' (2014: 80 ) discussion of the anarchist movement in Greece, for example, positions the establishment of Indymedia Athens in 2001 in the context of the broader history of opposition to fascism that existed in Greece even before WWII and the military junta of 1967. These examinations of the social movement's online connections then demonstrate the positioning of antifascist communication within a wider media ecology, at the local and international levels. The issue networks are not without their limitations: the purpose of this step is not to create a definitive overview of the antifascist movement's (public) connections, but to identify links between different groups, locally and internationally, which can be examined further through qualitative means through fieldwork and additional digital analysis. This research is supplemented by studying tweets and websites identified from the crawls and related hashtags, such as \#rbnews and \#free_indymedia, to highlight additional practices and frictions, and to further develop our analysis of the intersections between social movements and digital media.

Fieldwork and interviews for the project were carried out by Croeser and took place over five weeks in April and May 2013. This period serendipitously overlapped with events which, while by no means the most central event in the movement's history, offer a prism through which to view some of the frictions in Greek antifascist activists' use of different communicative technologies: the temporary shutdown of Athens Indymedia, Radio Entasi, and 98FM on 11 April 2013. This allowed access to debates taking place within the movement about which communicative technologies to use, how to approach and shape these technologies, and around long-term strategies for communication within the movement and with outside audiences. Fieldwork involved attendance at several meetings dealing with potential responses to the shutdown; protests around the shutdown ranging from small events (with approximately 30 participants) to a larger march (attended by approximately 4,000 people); and participation in a range of movement spaces, including radio stations and social centres. This provided valuable insights into discussions around activists' use of different technologies. 
In addition to this, in-depth, semi-structured interviews were carried out with 34 people associated with the movement, with attempts made to gather a range of perspectives. Snowball sampling with multiple starting points was an important factor in selecting participants, both as a way of triangulating participants considered to have useful insight into the movement and because personal introductions played an important role in convincing activists experiencing significant repression and surveillance to participate. Interviewees included those deeply involved in the antifascist movement who saw their involvement in independent media as part of this work; journalists working within mainstream media covering the rise of the far-right and nationalist political party Golden Dawn; people leading or working within immigrant groups; and those who saw themselves primarily as citizen or independent journalists. Together, these interviews allowed us to build a multi-layered perspective the movement, sharing commonalities with Tsing's use of a methodology that explores multiple viewpoints and is, 'variously ethnographic, journalistic, and archival ... formed in discrete patches' (2005: $\mathrm{x}$ ). Like Tsing, we are interested in 'odd connections rather than seamless generalizations, inclusive tables, or comparative grids.' (2005: xi).

Participants chose whether to be anonymous, or be identified by their legal names or a pseudonym. While offering all participants the option of anonymity is vital to ethical research, it is also important to recognise that some participants have compelling reasons to prefer being identified by name, or by a well-known pseudonym. One participant, IrateGreek, spoke of the protective value of visibility, knowing that the state would leave her alone because she has an international audience on Twitter. If we are to take seriously the injunctions to treat activists as those with the most valuable perspective on their own lives and work (Chesters, 2012: 145), we also need to respect their evaluations of the value and risk of public identification. Similarly, we have chosen our focus with care, particularly given that during the period of writing and research Greek media-both mainstream and independent-were increasingly under pressure from a range of directions; attacks on press freedoms in Greece were beginning to raise international concern well before our research was carried out (Borger, 2012). Like Tsing (2005: xii), we 'made choices about the kinds of research topics that seem appropriate, and, indeed, useful' based on our collaboration with activists. These, and other ethical issues related to our research methodology, are discussed in more detail in Croeser and Highfield (2015). 


\section{Frictions that slow, frictions that spark: activists' values and technological affordances}

The particular form of the Greek antifascist media ecology is shaped in part by the frictions that exist between activists' values and the embedded affordances of existing digital technologies. While, as we note above, the movement contains a wide range of politics, we have focused particularly on the work of anarchist and autonomist activists, who have been at the forefront of antifascist activism throughout recent Greek history (Kriditis, 2014; Kitis, 2015). The politics of these activists mean that they tend to value creating change on the ground rather than appealing to the government or other actors to change policy; autonomy and decentralisation; and an opposition to capitalism. These values shape, through friction, how different media are used. In particular, they lead to a significant presence for highly-localised websites linked to particular spaces within Athens (especially stekia * *'hangouts' or social centres), and extensive use of postering, which should be considered part of the media ecology in the same way that Twitter, Facebook, and Web radio are.

In addition to this, recent changes to antifascist communication practices are strongly tied to the shift away from Exarcheia, the anarchist and autonomous neighbourhood which has been the focal point for much of the Greek resistance to the right wing for decades. Now, some activists are working to decentralise the movement, shifting from Exarcheia towards neighbourhood assemblies, squats, and stekia around Athens. Squats, where local, disused spaces are occupied by activists, remain limited as a result of police repression and the dangers of attacks from fascist groups; this friction between activists and the state means that stekia, which are rented or otherwise legally acquired, play an important role in local organising. An activist from a social centre in the Zografou neighbourhood, Alex P, said in an interview, 'even us who were already involved in radical politics saw a lot of other chances to originate struggles, to create radical communities in neighbourhoods ... a lot of great things started happening in the neighbourhoods of Athens', which has been bringing new people to the movement. He said that, 'as the scene grew bigger the need for more communication and coordination was also getting bigger'. However, the choice of technologies for communication and organising is not always clear-cut.

The various digital platforms adopted by activists, and used for related topical coverage and political groups, form a digital media ecology of overlapping practices and local and international intersections. We used issue crawls to provide overviews of activist media networks originating from Greek sites, with one such network featured in Figure 1, arising from the seed list of antifascist websites. Here, independent media (including 
Athens Indymedia) and blogs receive links, as do social media and content-sharing platforms (Twitter, YouTube). What is also highlighted by the visualised networks are the connections between local and international groups and issues, with Figure 1, for instance, also featuring online resources dedicated to campaigns and themes around immigration elsewhere in Europe (such as the Calais Migrant Solidarity blog). Additional crawls, not depicted here, further emphasised the importance of location for online media, with blogs and online radio stations centred on specific parts of Athens being notable resources within the issue networks.

Figure 1, like the other issue networks identified for this project, is not without its limits; the crawls are not descriptive of the entire set of resources which are used by Greek activists, especially since not all activists are online, and communication also makes use of private

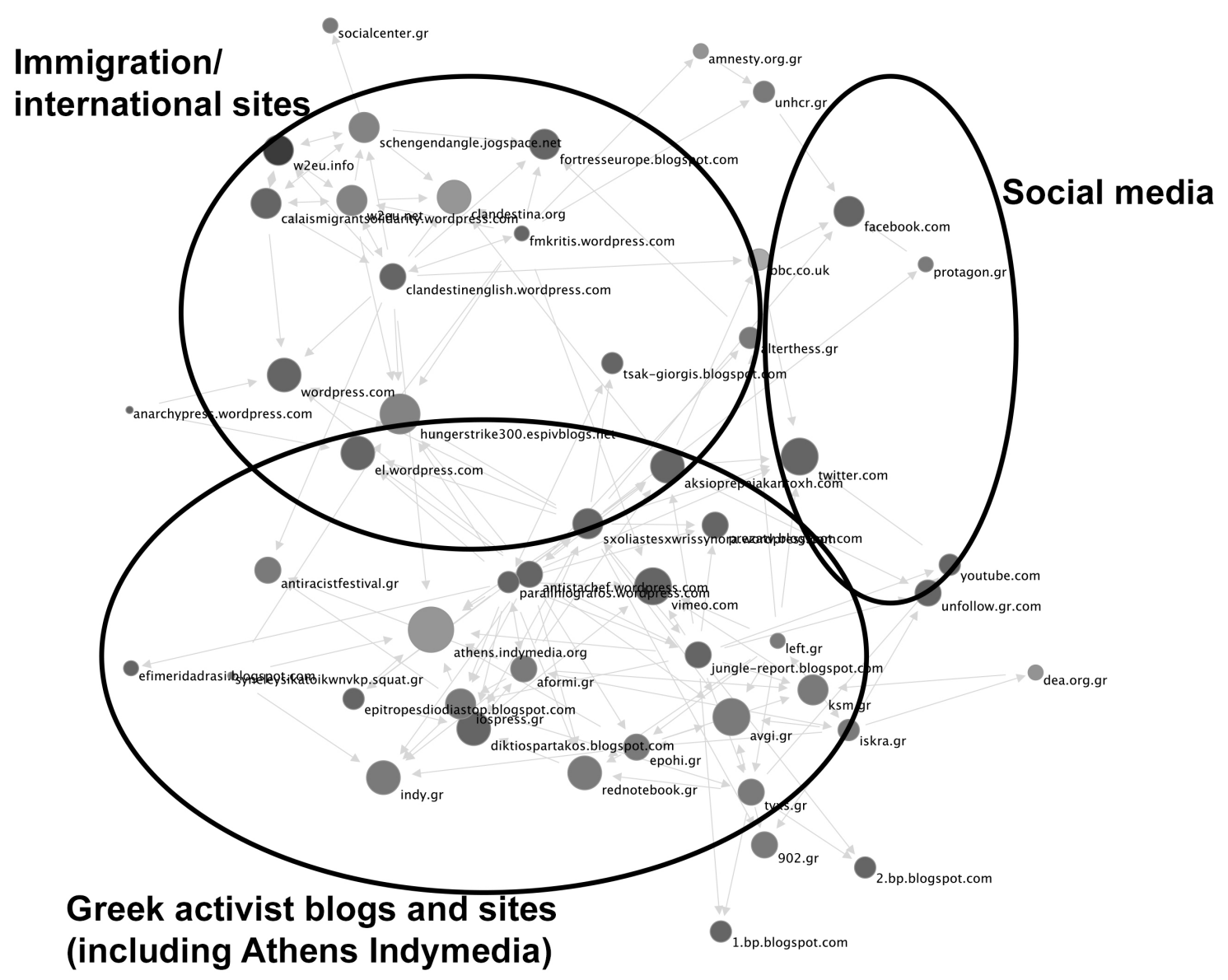

Figure 1: Antifascist issue network (crawl depth '2'), identified using IssueCrawler. [1] 
channels. Rather, the issue networks provide a visual aid for noting connections between sites and topics, which can be explored in further analysis using digital methods and through fieldwork. In Figure 1, for instance, among blogs hosted on Blogger and Wordpress, there are also topical resources featured on local, deliberately independent platforms like espivblogs. These crawls were carried out in April and May 2013; returning to the activist media ecology after the crawls also highlights the continued move towards independent and non-commercial spaces for activism online. The blog of the activist ACTION newspaper (efimeridadrasi.blogspot.com) featured to the left of Figure 1, for example, was moved from Blogger in late 2013 to a new site hosted through espiv.net (efimeridadrasi.espiv.net), as part of Greek activists' ongoing resistance towards corporate and commercial platforms.

Indeed, although blogs allow activists to maintain some control over content, form, and presentation, as opposed to social media platforms like Twitter or Facebook, even here concerns remain about censorship and surveillance, particularly for commercial services such as Blogger and Wordpress. Two activists who run a blog covering antifascist issues noted in an interview that they had specifically avoided using Blogger because of concerns with blogspot.gr being covered by Greek law, and had chosen Wordpress instead. However, they had been experiencing significant issues in the period after the Indymedia shutdown when traffic to their Wordpress site increased significantly: they were considering shifting the site and trying to find a new host service, preferably based outside of Europe and the US. Another anonymous participant argued that the online tools used by the movement:

...are structures for the movement, have been built by people from the movement, independent servers, and in a way, actually they are protecting data, and this is important for people who use those media, because other structures like Google and Wordpress are easily controlled by authorities.

Citizen-led platforms and initiatives, such as open radio and citizen journalism, give activists channels for their voices to be distinct and autonomous, particularly in response to distrust of the mainstream media. They also allow for these voices to potentially spread further, through sites such as RadioBubble where content is uploaded and shared. These platforms do not operate in isolation, but are closely interlinked, as seen in the physical connections (including using the same university space prior to the shutdown) and digital links between Athens Indymedia and 98FM. While the issue network visualisations do not in themselves explain why there are connections between sites, they do demonstrate the mix of commercial and independent platforms, and topical and geographic variations present around an initial thematic context such as the antifascist movement. These are in a state of flux, though: while commercial platforms like Twitter and Facebook offer 
a large-scale audience and centralised mechanisms for publicly sharing material, for instance, the risks and shortcomings around surveillance, privacy, and control of data and content, mean that movements are negotiating using these spaces while also promoting more independent options.

However, much of the existing literature takes it for granted that digital technologies mirror activists' values and priorities rather than questioning this process of negotiation. As a typical example, Kostis Kornetis (2010: 185) writes in his analysis of the 2008 protests that, 'Technology not only served as a vehicle of communication and co-ordination but also as the embodiment of the very political and organizational goals of the activists', combining discussion of independent and commercial media. Our research emphasises, in contrast, that activists' use of commercial and independent media is shaped by different frictions, some of which slow the use of particular technologies, while others lead to productive efforts to build alternatives.

Commercial platforms help in spreading information, promoting campaigns, and building the movement. Two activists interviewed noted that as well as hosting their site on a commercial blogging platform, many of their readers found them on Facebook, Twitter, and, somewhat surprisingly, Pinterest. Another, Persefoni, spoke about how Twitter has become a space in which people show support for and develop an identification with her local antifascist group:

...there was this guy who was saying, even though he has never showed up at our meetings, he said "ok, I am a member of anti-fascist group of [this neighbourhood], you have to go there," even though he wasn't a part of or joining our meetings, he felt he was a citizen of [the neighbourhood], but, you know, he felt that with his action, retweeting and tweeting, he would be a part of it ... he felt that he was contributing in a way.

This is in line with the significant body of literature which emphasises the value of Facebook, Twitter, and other commercial media to activists, while acknowledging the contestations and provocations within social media discussions (see, for example, Costanza-Chock, 2012; Tufekci and Wilson, 2012; Tufekci, 2013; Loza, 2014; Bonilla and Rosa, 2015).

At the same time, activists remain hesitant about these platforms. There is a broad recognition within the literature on activists' use of online communications that censorship 
and surveillance create friction, slowing or completely stopping the use of particular technologies (for more on this, see Croeser, 2012; Croeser and Highfield, 2014). The suspicions towards Twitter were reinforced in the fieldwork carried out for this study, and one of the results of authorities following social media activity in previous protests is that Greek activists are less willing to use popular commercial social media. One anonymous participant said:

...social media are not actually a free place, you know about this. Even authorities are checking what is published there, but they can be used in a radical way sometimes, and this happened in Libya, it's happened in Egypt, it's happened a lot, but in Greece it hasn't happened since [the 2008 protests].

While platforms such as Twitter can be used as tools for information dissemination and organisation by social movements, and attract attention from international audiences, Greek activists have proved resistant to fully adopting these popular social media, combining the use of these platforms with more independent sites. These practices highlight the negotiation of the need for public information-sharing and intra-movement communication and a desire to not be surveilled or monitored, leading to a productive friction concerning the types of technologies and their scopes for the movement.

However, there are also other frictions that emerge from activists' use of social media, including an ideological discomfort with the embedded values of commercial platforms. As Tsamou, involved in a group providing webmail and hosting services to activists, said, 'in Greece, people are very, let's say, hardcore for some things ... We don't want companies, we don't want sponsors or anything, we want our own infrastructure', relating this to the DIY trend in music which Kitis (2015) has cited as a key part of Greek anarchist and anti-authoritarian chóros. Censorship and surveillance of online spaces create friction that slows activists' use of particular platforms, but the commercial nature of these platforms is, perhaps, a greater source of friction for many antifascist activists who see capitalism and fascism as intertwined. While this kind of anti-capitalist resistance to using popular social media has received some attention in the literature (this is explicitly addressed in Neumayer and Valtysson, 2013:15 and implicit in much of the work on independent Web media, including Dunbar-Hester, 2009; 2012; 2014), more work is required to understand how activists negotiate the frictions between their own values and those embedded in social media.

The commitment to a DIY approach means that the Greek movement makes extensive use of older means of communicating online, with blogs, particularly independently-hosted 
blogs, and citizen journalism platforms enabling longer-form posting and more control over content, and Web radio all part of its communications. The popularity of blogs may in part have been encouraged by the actions of 2008, and the widespread critique of mainstream media associated with that period of protest: Mike Mowbray's (2010: 6) examinations of the 2008 Greek protests noted that 'it seems that each protest occupation in Greece had its own blog'. Blogs have remained vital and useful for Greek activists, especially given the comparatively more distributed nature of blogs as a preferred option over singular, corporate-run social media platforms like Twitter. This pattern is reflected in the issue networks identified for this project, where blogs were represented from a variety of hosting services and personal domains, using the major US services like Wordpress and Blogger but also Greek independent options like espivblogs.

These negotiations among Greek activists highlight how friction becomes a motivation for the adoption of new technologies (which create their own friction). The Indymedia shutdown encouraged activists to use increasingly independent and private channels for operating the site. In the immediate aftermath of the shutdown, the anonymity-focused network Tor, and its associated browser, were used to run and access Athens Indymedia. Tor's infrastructure involves the distribution and encrypted routing of web traffic to avoid surveillance and monitoring, concealing user information. However, the additional knowledge required to access Tor, and websites operated through it, made the transition less straightforward than simply changing social media or blog platforms. To this end, the indymedia.squat.gr site acted not as a mirror for the original Indymedia site, but as a how-to for activists (and other visitors) in the use of Tor to access Athens Indymedia. This information was also promoted on Twitter and on blogs, linking to the indymedia. squat.gr site and providing public details about how to access the less-public Indymedia. Providing clear, visible instructions may appear counter-intuitive, especially since the same opponents to activists might also make use of this information-although simply accessing the site through Tor is a very different proposition to attempting to shut down the Tor version. The squat website also confirmed that this approach was a very necessary and worthy step taken, as a means of continuing to support freedom of expression, counterinformation, and collective self-defence in response to state-led repression towards social movements (mammeloukos, 2013). Friction, in this case, was not simply the result of external oppression, but was also used creatively by activists.

This is also seen in the movement's responses to attacks on its physical infrastructure. The movement's communications and promotional strategies combine elements of the physical and the digital, but they also move between these different forms when others are unavailable. For example, activists are increasingly shifting their servers off university property since 2011, which saw the end of the asylum laws protecting Greek campuses from police incursions. Attacks on physical infrastructure (such as computers from squats 
being seized in police raids) are increasing attention to where servers are, and to the fundamental structures underlying communication networks. The work of activists in Athens has the potential to lead other movements to more autonomous communication practices: by demonstrating both how to successfully develop their own infrastructure, and the limitations and issues of popular, hosted services (including social media), activists may be persuaded to adopt more forms of alternative and independent media.

However, activists do not always choose to route around the damage caused by censorship. The Indymedia shutdown demonstrates that friction can become a way of making broader political structures visible and sparking action. Many of those interviewed said that there were multiple options available which would keep Indymedia up and running at its original address, including raising funds to host the site elsewhere and shifting to a mirror (as they did after some time). The decision to let the main site go down, to contest the shutdown, was a way of making visible the attack on universities as a space for dissent. In choosing not to take the path of least resistance, some activists saw themselves as recommitting to the idea of the university as an asylum and more broadly refusing to cede the idea of key spaces as public.

The loss of friction also becomes undesirable for some activists when the shift to independent media corresponds to a loss of the productive 'interconnection across distance' that Tsing cites as a key aspect of activism. Dimitra Milioni and Dionysus Panos (2011: 238) note that as 'the majority of the population shapes its understanding of the world through mass-mediated texts, especially during situations represented as crises, the communicative power of oppositional voices is limited within the partial online spheres, reaching only audiences that look for them'. Shifting away from Facebook, Twitter, or other mainstream commercial platforms also means giving up the potential to use these spaces to resist right-wing discourse or to engage with non-activist audiences. One person we interviewed talked about taking part in an ongoing 'war with fascists' on Facebook, and Twitter also serves as a public platform for debate. Theocharis et al. (2014) argue that the perception of 'very high levels of flaming and trolling in the Greek Twitter sphere' may have dissuaded many from use of the platform, leaving it to more engaged users. Indeed, Theocharis et al. found that Greek activists were not supportive of the platform 'being used predominantly for political mobilization and coordination' (2014: 208). However, during this case study, activists on Twitter using the \#free_indymedia hashtag were doing so in part to combat fascist comments made by public figures such as New Democracy MP Adonis Georgiadis (who is an active Twitter user); here, tweets were not just supporting Indymedia, but actively campaigning against (and trying to get Twitter to ban) intolerant and antagonistic views put forward by a member of the government. Online spaces outside of activist-run media have become important for those wishing to disrupt or contest Golden Dawn's narrative (Angouri and Wodak, 2014), as the Internet is a vector for Golden Dawn's 
growth (Koronaiu and Sakellariou, 2013: 332). Activists frequently seek out, rather than evade, points of friction.

Similarly, there was an effort to create friction in the life of the city in the march protesting the shut down; as one activist explained:

There is an effort from people who organise demonstrations, for the demonstrations not to be separated from the city, which can happen very easily, if the demo takes part in an empty road, or in a time when there is no actual traffic. Monastiraki is ... a place that if you gather you know that at least they will know that you gathered somewhere.

Online forms of communication and media are complemented with a strong focus on physical presence, which also offers its own forms of friction. The physical and the online are closely interlinked, as we also found in our study of Occupy Oakland (Croeser and Highfield, 2014): digital media can stand in for physical places when access is prevented, and serve coordinating and organisational roles for physical demonstrations, for example. Websites, blogs, and Web radio within the Greek context were also strongly connected to the physical locations in which they were located, specific to particular parts of Athens-and, as shown by the Indymedia shutdown, dependent on these locations and their physical infrastructure. At the same time, the digital is not the only communication approach for activists; ${ }^{* *}$ *postering, for example, plays a very significant role in the antifascist movement as a way to claim space and build a neighbourhood antifascist presence.

\section{Conclusion}

The practices surrounding digital technologies, and responses to specific platforms and challenges, within the context of Greek activism highlight the various perspectives and aims influencing the choices made by activists. Drawing on Tsing's (2005) model of friction allows us to build a more complex understanding of activists' use of digital technologies. Through our case study, we identified two key aspects in which activism and social movements are shaped, maintained, and recreated by productive friction. First, our analysis demonstrates that friction is created in multiple ways through the "creative connection across difference'. This is apparent not only between activists, but also between activists and technology. Within the Greek context, the apprehension directed 
towards commercial social media platforms, for instance, as controlled and surveilled spaces is also accompanied by an acknowledgement of their importance for sharing information and connecting groups in solidarity.

Second, the case study found that communicative practices which are (relatively) frictionfree are also frequently unproductive. Despite the promotion of the independence of activist platforms, for example, shifting entirely to independent media was not necessarily the most useful choice for the movement. Friction is not always unhelpful for social movements: it can offer a creative spark, inspiring change within-and beyond-the movement. Using independent digital platforms to communicate and host sites can provide a means of combating surveillance or censorship, but this can also be seen as a possible abandoning of commercial spaces to opposing voices: fascist and extremist groups make use of popular social media too, and the antifascist movement's negotiations towards using commercial and independent platforms includes the need to engage in order to resist and campaign against publicly inflammatory voices.

The antifascist movement itself is created (and continually recreated) through a process of productive friction, as different groups and individuals with varying (and sometimes clashing) ideologies and experiences work together. Digital technologies become important sites for this friction, as well as for friction between activists, the state, and capital. While there may be paths of less resistance, they are not always the most desirable for activists, and there are no entirely frictionless strategies for using digital technologies, whether they are independent or commercial. Activists at times respond to friction by attempting to shift to a smoother pathway, but at other times friction is used as a creative spark for change within the movement, or in society more broadly.

Athens Indymedia helps to illustrate our argument about the place and role of friction within social movements. The uses of digital technologies by the activists studied here links back to Tsing's exploration of connections across difference, between human and non-human actors as well as at the interpersonal level. The movement is not solely the work of activists, but is shaped by the choices of technologies and strategies, of issues and responses. These frictions and negotiations will continue to be critical for studies of social movements and social media: the balance between public and private, independent and commercial, and ongoing debates around data retention, surveillance, and profiling, will provide further sparks for activists in their uses-or non-uses-of digital technologies as tools of communication, organisation, and dissent. 


\section{Biographical Note}

Sky Croeser is an Adjunct Research Fellow in the Department of Internet Studies at Curtin University.

Tim Highfield is a Postdoctoral Research Fellow in Media and Communication at Queensland University of Technology, and a Sessional Academic in Internet Studies at Curtin University.

\section{Acknowledgement}

The authors would like to thank all of those who consented to be interviewed for this project, including those who provided detailed feedback on the draft, and Maria Sidiropoulos for her invaluable research assistance in producing seed lists for the issue networks and interview transcription.

\section{Notes}

[1] IssueCrawler colours nodes based on the source domain, distinguishing between, for instance, .com and .gr addresses. This colouring is not necessarily helpful for our analysis, though, given the use of blogging platforms at the .com and .net level as well as .gr. Node size is based on in-degree, with sites receiving more links from others in the network appearing larger in the visualisation. The annotations provided here are loose topical descriptions and not representative of all sites within the corresponding sections of the network. 


\section{References}

Angouri, Jo and Ruth Wodak. "They Became Big in the Shadow of the Crisis": The Greek Success Story and the Rise of the Far Right', Discourse \& Society 25.4 (2014): 540-565.

Baboulias, Yiannis. 'The Greek Government are Silencing their People', Vice UK, 16 April (2013), http://www.vice.com/en_uk/read/the-greek-government-shut-down-indymedia

Bennett, W. Lance and Alexandra Segerberg. The Logic of Connective Action: Digital Media and the Personalization of Contentious Politics (New York, NY: Cambridge University Press, 2013).

Bonilla, Yarimar and Rosa, Jonathan. '\#Ferguson: Digital Protest, Hashtag Ethnography, and the Racial Politics of Social Media in the United States', American Ethnologist 42.1 (2015): 4-17.

Borger, Julian. 'Greek Journalists Warn over Press Freedom', The Guardian, 29 October* *(2012), http://www.theguardian.com/world/2012/oct/29/greek-journalists-warn-press-freedom

Chatzidakis, Andreas. 'Commodity Fights in Post-2008 Athens: Zapatistas Coffee, Kropotkinian Drinks and Fascist Rice', Ephemera: Theory \& Politics in Organization 13.2 (2013): 459-468.

Chesters, Graeme. 'Social Movements and the Ethics of Knowledge Production', Social Movement Studies 11.2 (2012): 145-160.

Costanza-Chock, Sasha. 'Mic Check! Media Cultures and the Occupy Movement', Social Movement Studies: Journal of Social, Cultural and Political Protest 11.3-4 (2012): 375-385.

Croeser, Sky. 'Contested Technologies: The Emergence of the Digital Liberties Movement', First Monday 17.8 (2012), http://firstmonday.org/ojs/index.php/fm/article/view/4162/3282

Croeser, Sky. Global Justice and the Politics of Information: The Struggle over Knowledge. (Hoboken, NJ: Routledge, 2014).

Croeser, Sky and Tim Highfield. 'Occupy Oakland and \#oo: Uses of Twitter within the Occupy movement', First Monday 19.3 (2014), http://firstmonday.org/ojs/index.php/fm/article/ view/4827

Croeser, Sky and Highfield, Tim. 'Mapping Movements-Social Movement Research and Big Data: Critiques and Alternatives', in Ganaele Langlois, Joanna Redden and Greg Elmer (eds). Compromised Data: From Social Media to Big Data (London: Bloomsbury, 2015 (in press)).

Dalakoglou, Dimitris and Antonis Vradis. 'Introduction', in Antonis Vradis and Dimitris Dalakoglou (eds). Revolt and Crisis in Greece: Between a Present Yet to Pass and a Future Still to Come (Oakland, Baltimore, Edinburgh, London \& Athens: AK Press and Occupied London, 2011), 13-25. 
Dalakoglou, Dimitris. 'Neo-Nazism and Neoliberalism: A Few Comments on Violence in Athens At the Time of Crisis', WorkingUSA 16.2 (2013): 283-292.

Dunbar-Hester, Christina. "Free the Spectrum!" Activist Encounters with Old and New Media Technology', New Media \& Society 11.1-2 (2009): 221-240.

Dunbar-Hester, Christina. 'Soldering Toward Media Democracy Technical Practice as Symbolic Value in Radio Activism', Journal of Communication Inquiry 36.2 (2012): 149-169.****

Dunbar-Hester, Christina. 'Producing "Participation"? The Pleasures and Perils of Technical Engagement in Radio Activism', Public Culture, 26.1 (2014): 25-50.

Gerbaudo, Paulo. Tweets and the Streets: Social Media and Contemporary Activism (London: Pluto Press, 2012).

Giovanopoulos, Christos and Dimitris Dalakoglou. 'From Ruptures to Eruption: Genealogy of the December 2008 Revolt in Greece', in Antonis Vradis and Dimitris Dalakoglou (eds). Revolt and Crisis in Greece: Between a Present Yet to Pass and a Future Still to Come (Oakland, Baltimore, Edinburgh, London \& Athens: AK Press and Occupied London, 2011), 91-114.

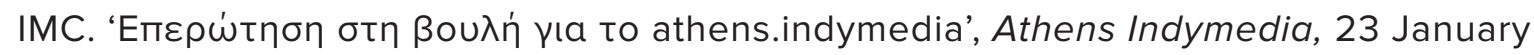
(2009), https://athens.indymedia.org/post/976610/

Inflammatory. 'A Map of Greece's Media Corrupt Relationships (part 1)', RadioBubble, 17 June (2013), http://international.radiobubble.gr/2013/06/a-map-of-greeces-media-corruptrelations.html

Kalyvas, Andreas. 'An Anomaly? Some Reflections on the Greek December 2008', Constellations 17.2 (2010): 351-365.

Karamichas, John. 'The December 2008 Riots in Greece', Social Movement Studies 8. 3 (2009): 289-293.

Kitis, E. Dimitris. 'The Anti-Authoritarian Chóros: A Space for Youth Socialization and Radicalization in Greece (1974-2010)', Journal for the Study of Radicalism 9.1 (2015): 1-36.

Kondilis, Elias, Giannakopoulos, Stathis, Gavana, Magda, Benos, Alexis, lerodiakonou, loanna and Waitzkin, Howard. 'Economic Crisis, Restrictive Policies, and the Population's Health and Health Care: The Greek Case', American Journal of Public Health 103.6 (2013): 973-979.

Kornetis, Kostis. 'No More Heroes? Rejection and Reverberation of the Past in the 2008 Events in Greece', Journal of Modern Greek Studies 28. 2 (2010): 173-197.

Koronaiou, Alexandra and Alexandros Sakellariou. 'Reflections on "Golden Dawn", Community Organizing and Nationalist Solidarity: Helping (only) Greeks', Community Development Journal 48.2 (2013): 332-338.

Kritidis, Gregor. 'The Rise and Crisis of the Anarchist and Libertarian Movement in Greece, 1973-2012', in Bart van der Steen, Ask Katzeff, and Leendert van Hoogenhuijze (eds).* The 
City Is Ours: Squatting and Autonomous Movements in Europe from the 1970s to the Present* (Oakland, CA: PM Press, 2014), 63-94.

Lowen, Mark. 'Greeks Strike Over Media Closure', BBC News, 13 June**(2013), http://www. bbc.co.uk/news/world-europe-22883236

Loza, Susana. 'Hashtag Feminism, \#SolidaritylsForWhiteWomen, and the Other \#FemFuture', Ada: A Journal of Gender, New Media, and Technology 5 (2014): http://adanewmedia. org/2014/07/issue5-loza/

Makrygianni, Vaso and Haris Tsavdaroglou. 'Urban Planning and Revolt: A Spatial Analysis of the December 2008 Uprising in Athens', in Antonis Vradis and Dimitris Dalakoglou (eds). Revolt and Crisis in Greece: Between a Present Yet to Pass and a Future Still to Come (Oakland, Baltimore, Edinburgh, London \& Athens: AK Press and Occupied London, 2011), $29-57$.

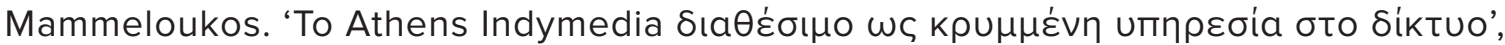
Athens Indymedia (squat.gr) 11 April**(2013), http://indymedia.squat.gr/2013/04/to-athens-

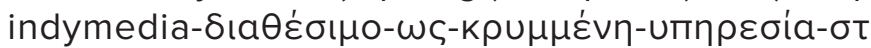

Margaronis, Maria. 'Fear and Loathing in Athens: The Rise of Golden Dawn and the Far Right', the Guardian newspaper, 26 October (2012), http://www.theguardian.com/ world/2012/oct/26/golden-dawn-greece-far-right

Marres, Noortje and Richard Rogers. 'Recipe for Tracing the Fate of Issues and their Publics on the Web', in Bruno Latour and Peter Weibel (eds). Making Things Public: Atmospheres of Democracy (Cambridge, MA: MIT Press, 2005), 922-935.

Meikle, Graham. Future Active: Media Activism and the Internet (New York, NY: Routledge, 2002).

Milioni, Dimitra L. 'Probing the Online Counterpublic Sphere: The Case of Indymedia Athens', Media, Culture \& Society 31.3 (2009): 409-431.

Milioni, Dimitra L. and Dionysis Panos. 'New Media and Radical Protest: Reflections from the "Greek 2008 Riots", International Journal of Media \& Cultural Politics 7.2 (2011): 233-240.

Mowbray, Mike. 'Blogging the Greek Riots: Between Aftermath and Ongoing Engagement', Resistance Studies Magazine (2010): 4-15.

Neumayer, Christina and Bjarki Valtysson. 'Tweet against Nazis? Twitter, Power, and Networked Publics in Anti-Fascist Protests', MedieKultur. Journal of Media and Communication Research 29.55 (2013): http://ojs.statsbiblioteket.dk/index.php/mediekultur/article/ view/7905

Occupied London Collective. 'Capitalism by Default', in Antonis Vradis and Dimitris Dalakoglou (eds). Revolt and Crisis in Greece: Between a Present Yet to Pass and a Future Still to Come (Oakland, Baltimore, Edinburgh, London \& Athens: AK Press and Occupied London, 2011), 328-331.

Papacharissi, Zizi. Affective Publics: Sentiment, Technology, and Politics. (Oxford: Oxford 
University Press, 2015).

Psarras, Dmitris. The Rise of the Neo-Nazi party "Golden Dawn" in Greece: Neo-Nazi mobilisation in the Wake of Crisis. (Brussels/Athens: Rosa-Luxemburg-Stiftung, 2013).

Siapera, Eugenia. 'Golden Dawn and the Social Media Wars', The Press Project (2014, May 6), http://www.thepressproject.net/article/61294/Golden-Dawn-and-the-Wars-on-Facebook

Sotiris, Panagiotis. 'Rebels with a Cause: The December 2008 Greek Youth Movement as the Condensation of Deeper Social and Political Contradictions', International Journal of Urban and Regional Research 34.1 (2010): 203-209.

Theocharis, Yannis, Lowe, Will, van Deth, Jan W. and García-Albacete, Gema. 'Using Twitter to Mobilize Protest Action: Online Mobilization Patterns and Action Repertoires in the Occupy Wall Street, Indignados, and Aganaktismenoi Movements', Information, Communication \& Society 18.2 (2014): 202-220.

Tsing, Anna Lowenhaupt. Friction: An Ethnography of Global Connection (Princeton N.J.: Princeton University Press, 2005).

Tufekci, Zeynip. “'Not This One”: Social Movements, the Attention Economy, and Microcelebrity Networked Activism', American Behavioral Scientist 57.7 (2013): 848-870.

Tufekci, Zeynip and Christopher Wilson. 'Social Media and the Decision to Participate in Political Protest: Observations from Tahrir Square', Journal of Communication 62.2 (2012): 363-379.

Vatikiotis, Pantelis. 'Networking Activism: Implications for Greece', Estudos Em Comunicação 10 (2011): 163-179.

Vradis, Antonis and Dalakoglou, Dimitris (eds). Revolt and Crisis in Greece: Between a Present Yet to Pass and a Future Still to Come (Oakland, CA: AK Press and Occupied London, 2011).

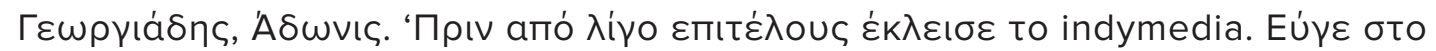

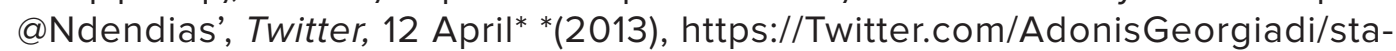
tus/322419853577318400

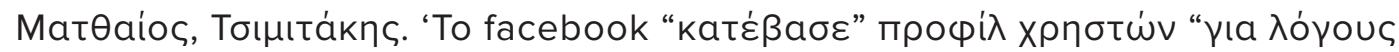

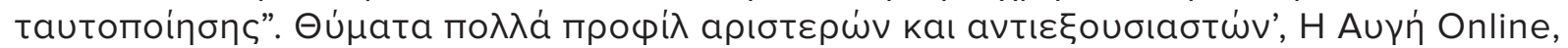
5 June (2013), https://www.avgi.gr/article/414765/to-facebook-katebase-profil-xriston-gialogous-tautopoiisis-thumata-polla-profil-aristeron-kai-antiexousiaston 
The LOCKSS System has the permission to collect, preserve and serve this open access

Archival Unit

This Isuue of the Fibreculture Journal by The Fibreculture Journal Incorporated is licensed under a Creative Commons Attribution 4.0 International License.

\section{OPEN HUMANITIES PRESS}

The Fibreculture Journal is published by The Fibreculture Journal Incorporated in partnership with Open Humanities Press. 